\title{
PEMBUATAN MEMBRAN SERAT BERONGGA POLIETERSULFON/2- (METAKRILOILOSI)ETIL POSPORIL KLORIN DAN APLIKASINYA UNTUK PENGOLAHAN AIR SUMUR TERCEMAR LIMBAH TSUNAMI DI BANDA ACEH (Preparation Hollow Fiber Membrane of Polyethersulfone/2-(Methacryloyloxy)Ethyl Phosphoryl Chlorine and Its Application for The Treatment of Well Water Contaminated with The Tsunami Waste in Banda Aceh)
}

\author{
Sri Aprilia dan Nasrul Arahman* \\ *Jurusan Teknik Kimia, Fakultas Teknik, Universitas Syiah Kuala \\ Jalan Syech Abdurrauf No 7, Darussalam, Banda Aceh 23111.
}

*Penulis korespondensi. No Tel: +6281360927917. Email: nasrular@unsyiah.ac.id

Diterima: 15 September 2015

Disetujui: 29 Oktober 2015

\begin{abstract}
Abstrak
Banyak kasus air sumur masyarakat di wilayah yang terkena imbas tsunami di Banda Aceh mengandung zat padat terlarut (Total Dissolved Solid, TDS) dan klorida melebihi standar baku mutu untuk pertimbangan kesehatan. Diperlukan perlakuan khusus untuk menghilangkan zat padat terlarut dan klorida dari air tersebut. Teknologi membran telah diperkenalkan secara luas sebagai teknik yang menjanjikan untuk produksi air bersih dengan kualitas tinggi. Pada penelitian ini, teknik separasi dengan lapisan membran digunakan untuk memisahkan kandungan zat padat terlarut dan klorida dari sampel air sumur masyarakat Banda Aceh yang terkena tsunami. Membran serat berongga dibuat dengan melarutkan polietersulfon and 2-(metakriloiloksi)etil posporil klorin ke dalam pelarut N-metil-2-pirolidon. Studi ini mempelajari pengaruh konsentrasi membran modifying agent terhadap struktur morfologi membran yang dihasilkan. Kemudian kinerja membran terhadap filtrasi dilakukan dengan menggunakan air deionisasi. Lebih lanjut, kinerja membran dilakukan untuk mengurangi kadar kekeruhan, TDS, $\mathrm{CaCO}_{3}, \mathrm{Cl}, \mathrm{NO}_{3}, \mathrm{NO}_{2}$, total coliform, dan bakteri Escherichia coli dari sampel air sumur. Hasil ekperimen menunjukkan bahwa semua parameter yang diuji dapat dikurangi sampai nilainya berada di bawah standar baku mutu air bersih.
\end{abstract}

Kata kunci: Air bersih, air sumur terkontaminasi, membran modifikasi serat berongga, dan zat padat terlarut.

\begin{abstract}
In many cases well water on tsunami affected area of Banda Aceh contains the Total Dissolved Solid (TDS) and chloride in high concentration over the drinking water level for general good health consideration. A special treatments are needed to remove the TDS and chloride in water. Membrane technology have been widely introduced as an emerging technique to produce high quality of clean water. In this work, membrane separations are proposed to remove TDS and chloride from well water of community in tsunami affected area of Banda Aceh. Membrane hollow fiber was prepared by dissolving of polyethersulfone and 2-(methacryloyloxy)ethyl phosphoryl chlorine in N-methyl-2-pirrolydone. The effect of membrane modifying agent concentration studied on the morphology of resulted membrane. The fabricated membrane was used to observe the filtration performance of deionized water by using single module of hollow fiber membrane. In addition, the membrane was used to remove turbidity, $\mathrm{TDS}, \mathrm{CaCO}, \mathrm{Cl}, \mathrm{NO}_{3}, \mathrm{NO}_{2}$, total coliform, and Escherichia Coli bacteria from sample of well water. The experimental result showed that all parameter can be reduced and those concentration was under the quality standard of drinking water.
\end{abstract}

Keywords: Clean water, contaminated well water, total dissolve solid, and hollow fiber modification membrane.

\section{PENDAHULUAN}

Gempa bumi yang diikuti dengan tsunami pada tanggal 26 Desember 2014 di Aceh telah menyebabkan kerusakan sarana dan prasarana kehidupan masyarakat (Matsumaru, dkk. 2012). Salah satu dampak yang cukup serius adalah penurunan kualitas sumber air, khususnya kualitas air sumur masyarakat Banda Aceh dan sekitarnya. Air sumur sebagai salah satu sumber air minum bagi sebagian warga Banda Aceh dan Aceh Besar telah terkontaminasi oleh limbah air tsunami. Widyastuti dkk (2012), menyatakan bahwa air sumur dapat terkontaminasi karena kerentanan spesifik yang didasarkan pada karakteristik unsur dan kelompok unsur pencemar karena ada kaitannya dengan sistem hidrogeologi. Kedalaman muka air tanah yang terlalu rendah pada sumur gali akan dapat mempengaruhi bahan pencemar (Miswadi, 2009).

Kualitas air sumur masyarakat di banyak wilayah telah melampaui standar baku mutu air yang sesuai dengan standar kesehatan. Air sumur 
mengandung padatan terlarut sampai tiga kali lebih tinggi dari standar baku mutu. Selain itu, kandungan total coliform mencapai 5000 per $\mathrm{mL}$ air (Ilyas dkk., 2006). Seiring dengan proses rehabilitasi dan rekonstruksi Aceh pasca tsunami, jumlah penduduk Kota Banda Aceh meningkat drastis. Kebutuhan air bersih dalam jumlah yang cukup dan kualitas yang baik mutlak diperlukan. Sementara itu perusahaan daerah air minum tidak bisa mencukupi suplai air kepada seluruh masyarakat Banda Aceh. Oleh karena itu, pencarian metode alternatif diperlukan untuk mengolah air baku sebagai pengganti pemanfaatan air sumur bagi masyarakat.

Pada proses pengolahan air minum secara konvensional, bakteri patogen dihilangkan pada tahap desinfeksi dengan proses klorinasi karena biaya yang murah dan kemampuan membunuh bakteri yang baik. Namun, selama proses desinfeksi, klorin berpotensi bereaksi dengan bahan organik terlarut di dalam air baku membentuk sejumlah produk samping desinfeksi yang dikenal dengan disinfection by-products (DBPs) (Chu, dkk., 2013). Produk-produk DBP yang telah dideteksi adalah trihalomethane (THM), haloacetic acid (HAA), asam bromokloroasetat, monokloroamin, serta ada 10 jenis lainnya (Culin dan Mustac, 2015). THM terbentuk karena reaksi antara klorin dan bahan organik baik yang ada pada air baku maupun pada proses distribusi air (Kumari dkk., 2015; Chowdhury dkk., 2010). Produk DBPS ini telah diindentifikasi memiliki aktivitas genotoksik, mutagenic, dan karsiogenik (Sun, 2009).

Salah satu metode pengolahan air bersih yang menjanjikan keunggulan dari segi kualitas air yang dihasilkan adalah dengan teknik filtrasi membran. Teknik pemisahan dengan teknologi membran telah berkembang dan diaplikasikan secara luas dalam industri pengolahan air sebagai alternatif pengolahan konvensional seperti; koagulasi, sedimentasi, dan filtrasi dengan media pasir (Mohammad dkk., 2015, Su dkk., 2015). Aplikasi membran untuk memproduksi air dalam jumlah besar akan jauh lebih menguntungkan jika dibandingkan dengan proses konvensional. Teknologi membran (ultrafiltrasi dan mikrofiltrasi) mulai diperkenalkan dalam skala besar sejak tahun 1980 (Baker, 2004). Selanjutnya teknologi ini berkembang pesat karena peralihan metode pengolahan air secara konvensional ke teknologi membran di negara-negara maju seperti Amerika, Jepang, dan China. Selain itu, pertumbuhan produksi membran dunia meningkat tajam dalam beberapa tahun terakhir karena kebutuhan untuk proses pemurnian air dalam mengatasi keterbatasan penyediaan air bersih di beberapa negara Timur Tengah, Afrika, dan Asia.
Beberapa keunggulan teknologi pemisahan dengan membran yaitu mampu menyaring bahanbahan pencemar dalam rentang yang luas. Proses operasi filtrasi dengan membran lebih mudah/sederhana dan membutuhkan biaya lebih rendah baik untuk operasi maupun pemeliharaan alat, lay-out proses lebih kecil, minim pemakaian bahan kimia, dan mampu merejek bakteri pathogen sampai 100\% (Pearce, 2007, Arahman, dkk., 2011).

Penelitian ini menawarkan konsep pengolahan air bersih menggunakan membran serat berongga yang terbuat dari polimer polietersulfon dengan beberapa modifikasi struktur morfologi. Digunakan sampel air sumur masyarakat yang pernah tercemar limbah air tsunami pada tahun 2004. Tujuan penelitian adalah untuk mempelajari pengaruh modifikasi struktur pori membran dengan polietersulfon terhadap kemampuan penyisihan parameter kimia dan biologi dari air sumur masyarakat. Parameter tersebut berupa kekeruhan, total zat padat terlarut, kalsium karbonat, klorida, nitrat, nitrit, total coliform, dan Escherichia coli.

\section{METODE PENELITIAN}

\section{Bahan dan alat}

Sejumlah bahan kimia yang digunakan untuk pembuatan membran adalah polimer polietersulfon (PES), pelarut N-metil-2-pirrolidon (NMP), aditif polivinil pirolidon (PVP), dan 2-(metilkriloilosi)etil posporil klorin (MPC). Untuk mengetahui kemampuan rejeksi membran terhadap zat pencemar air digunakan asam humat (humic acid). Untuk proses ultrafiltrasi digunakan air sumur masyarakat Banda Aceh di wilayah Kecamatan Syiah Kuala. Peralatan yang digunakan terdiri dari satu set alat pencetak membran serat berongga, dan peralatan analisa struktur morfologi membran yang terdiri dari Scanning Electron Microscopy (SEM), dan Atomic Force Microscopy (AFM).

\section{Prosedur \\ Proses pembuatan membran}

Membran hollow fiber poliethersulfon dibuat dengan metode inversi fasa oleh non-pelarut (nonsolvent induced phase separation, NIPS). Metode ini dikenal dengan istilah dry-wet spinning process. Larutan polimer dibuat dengan melarutkan PES ke dalam pelarut NMP dengan konsentrasi konstan $20 \%$ (berat) untuk semua jenis membran. Dibuat satu jenis membran dengan komposisi PES tanpa penambahan aditif (UF1). Selanjutnya dibuat 3 jenis membran lainnya dengan penambahan aditif polimer masing-masing PES+MPC0 : 5\% (UF2), PES+MPC : 1\% (UF3), dan PES+PVP : 2\% MPC : 1\% (UF4).

Proses pembuatan membran serat berongga mengikuti prosedur yang telah dijelaskan pada 
sebelumnya, sebagaimana diperlihatkan pada Gambar 1 (Arahman dkk., 2011). Dimulai dengan memasukkan larutan polimer ke dalam tangki dope. Selanjutnya larutan polimer ini dialirkan dari tangki larutan dope melewati spinneret menggunakan pompa tipe roda gigi. Larutan non-solvent dalam hal ini air, diinjeksikan ke bagian tengah spinneret untuk membentuk rongga dari fiber. Fiber ditarik ke dalam tangki koagulasi yang berisi air sebagai non-solvent supaya terjadi pemisahan fasa dan memadatkan membran menggunakan motor pemutar (take-up winder). Laju alir polimer melalui spinneret dikontrol dengan pompa tipe roda gigi. Spinneret terdiri dari tube bagian luar dan bagian dalam dengan diameter masing masing 1,00 dan $0,70 \mathrm{~mm}$. Membran yang terbentuk disimpan dalam air deionisasi sebelum dilakukan pengujian dan karakterisasi.

\section{Analisis morfologi membran}

Semua membran yang telah dibuat selanjutnya dianalisis struktur morfologi menggunakan peralatan SEM dan AFM. SEM digunakan untuk melihat bentuk struktur pori pada penampang melintang membran dan pada dinding macrovoid. Sementara AFM digunakan untuk menganalisis bentuk nodule pada permukaan membran.

\section{Uji ultrafiltasi air sumur}

Uji ultrafiltrasi dilakukan dengan menggunakan modul tunggal membran serat berongga. Tahap pertama ultrafiltrasi menggunakan umpan air deionasi pada tekanan operasi $0,5 \mathrm{~atm}$ dengan tipe aliran umpan pressure driven inside (aliran umpan dari dalam menuju dinding luar membran serat berongga). Larutan umpan dipompakan menuju lapisan membran menggunakan pompa peristaltik dengan debit yang ditetapkan. Air yang melewati lapisan membran (permeat) dari luar dinding membran dikumpulkan setiap periode waktu tertentu. Untuk mengetahui daya rejeksi membran terhadap foulant, digunakan asam humat sebagai larutan umpan. Konsentrasi asam humat dalam umpan dan dalam permeat dianalisis menggunakan spektrofotometer. Selanjutnya proses filtrasi dilakukan menggunakan air sumur masyarakat Banda Aceh yang pernah terkena aliran limbah tsunami tahun 2004.

\section{HASIL DAN PEMBAHASAN}

\section{Struktur Morfologi Penampang Membran}

Struktur pori membran merupakan salah satu parameter yang menentukan keberhasilan proses ultrafiltrasi. Pada pembuatan membran, pembentukan struktur pori ini dipengaruhi oleh jenis dan komposisi polimer, jenis dan komposisi pelarut, serta jenis dan komposisi zat aditif (Martin dkk., 2015). Perusahaan pembuat membran serta peneliti mengembangkan membran dengan kinerja terbaik melalui memodifikasi jenis dan komposisi ketiga komponen tersebut. Dasar pertimbangan penentuan komposisi material membran adalah ukuran partikel komponen yang dipisahkan saat membran diaplikasikan.

Gambar 2(a) memperlihatkan bentuk membran UF1 yang dihasilkan pada penelitian ini. Membran berbentuk silinder dengan diameter dalam rata-rata $1 \mathrm{~mm}$ dan panjang konstan $15 \mathrm{~cm}$. Gambar 2(b) merupakan foto pembesaran penampang melintang keseluruhan (whole cross-section) membran UF1 hasil foto SEM dengan magnifikasi 70 kali. Terlihat struktur morfologi membran bagian penampang terdiri dari empat lapisan yaitu lapisan kulit permukaan atas, struktur microvoid di bawah permukaan atas, struktur sponge dan struktur macrovoid bagian tengah, serta struktur dense bagian permukaan dalam. Umumnya membran yang diproduksi dengan metode inversi fasa secara $d r y$ wet inversion atau biasa disebut dengan metode nonsolvent induced phase separation (NIPS) memiliki struktur pori seperti ini (Martin dkk., 2015, Kumar dkk., 2013). Modifikasi material larutan polimer dan modifikasi kondisi proses pembuatan membran akan Larutan dope

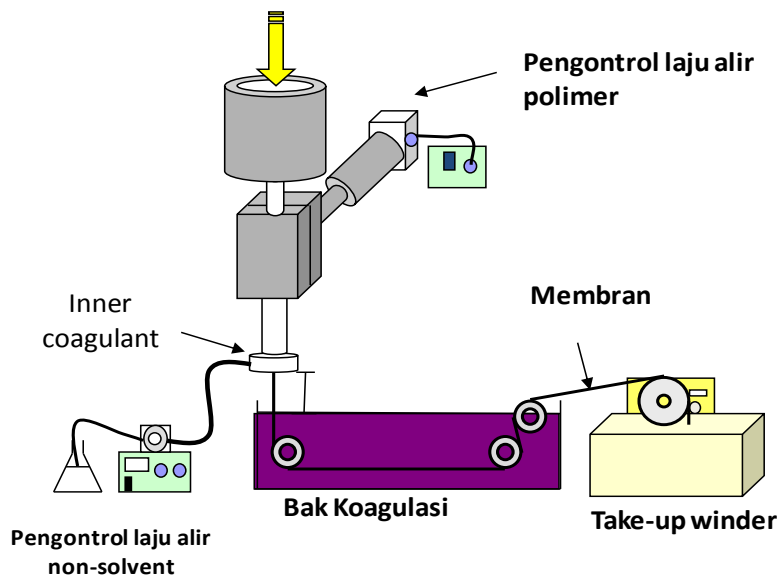

Gambar 1. Skema peralatan pembuatan membran (Arahman dkk., 2011)

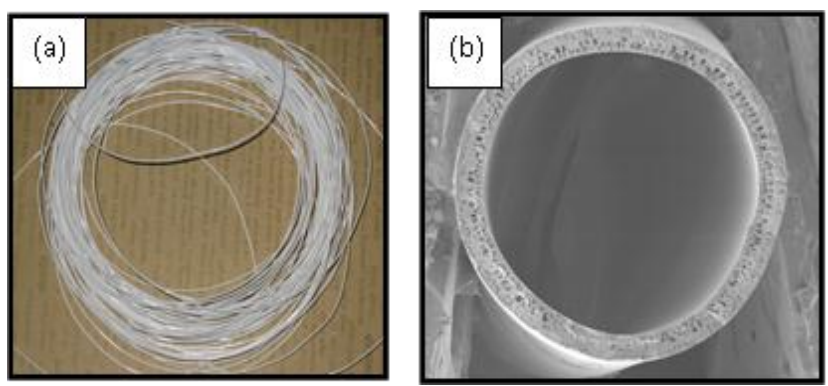

Gambar 2. Membran UF1 difoto dengan kamera digital Canon SD900 (a), dan penampang melintang keseluruhan membran UF1 difoto dengan Fe-SEM JEOL pembesaran 70x (b). 


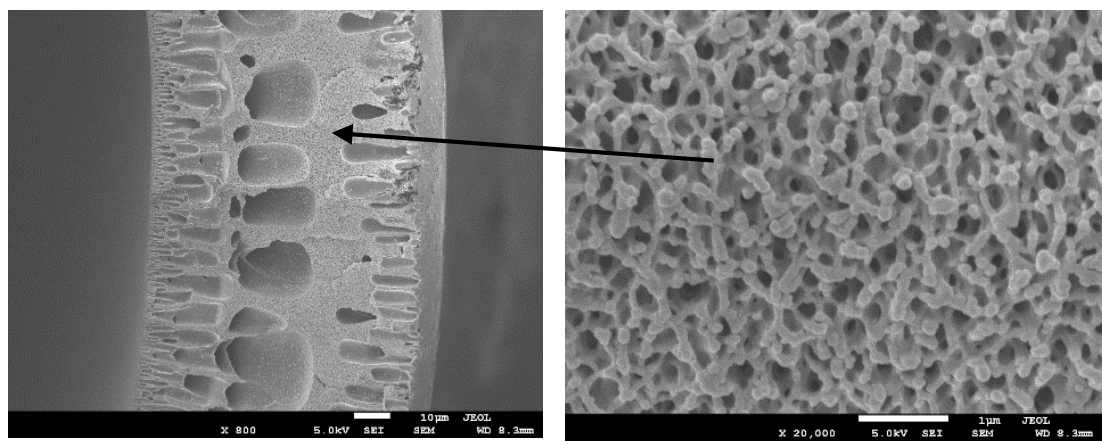

a. UF1

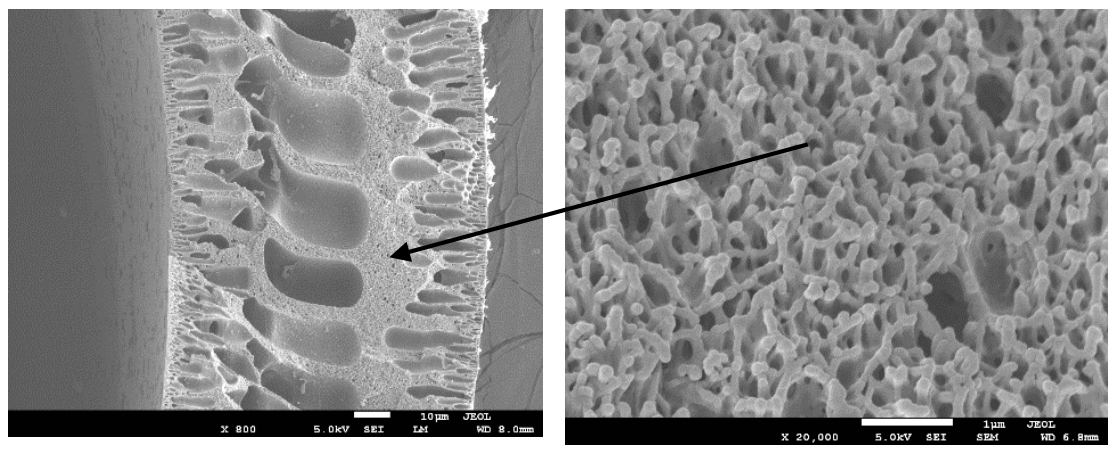

b. UF2

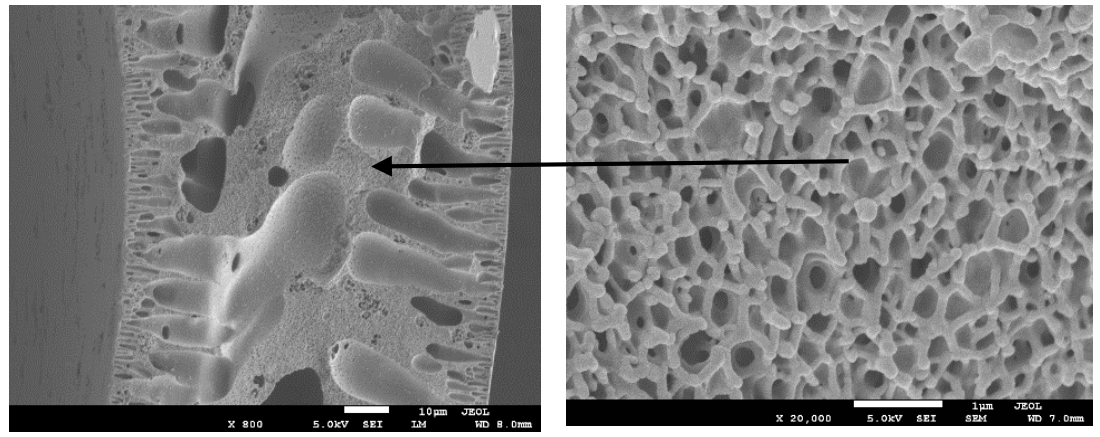

c. UF3

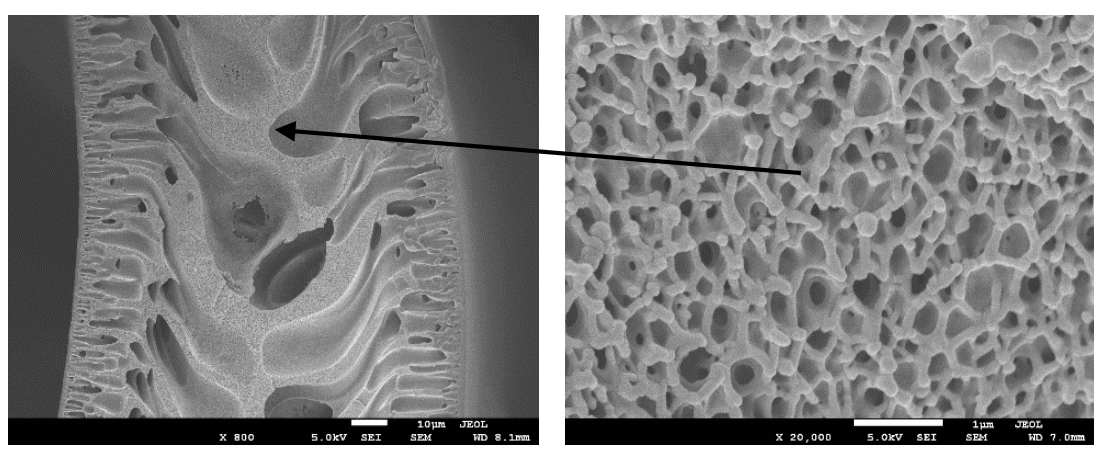

d. UF4

Gambar 3. Struktur morfologi membran hollow fiber bagian penampang melintang. Struktur sponge membran UF2 ini juga lebih kecil daripada membran UF1.

berpengaruh kepada ukuran keempat bentuk struktur tersebut. Membran yang diproduksi secara NIPS umumnya digunakan untuk proses ultrafiltrasi/ mikrofiltrasi pada proses pengolahan air bersih dan pengolahan air limbah. Membran jenis ini juga lazim diaplikasikan untuk pemurnian protein dan pembuatan jus. 

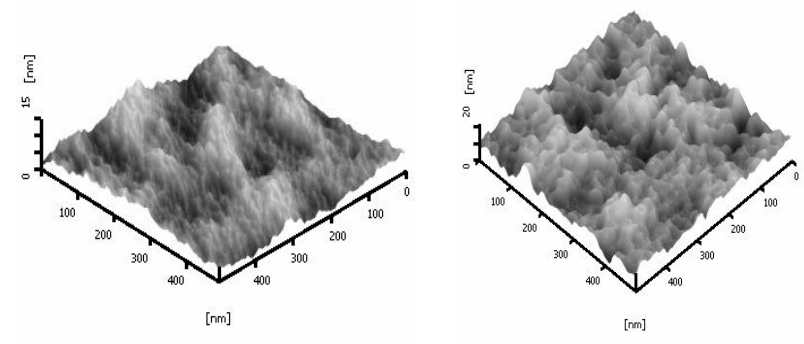

a. UF1

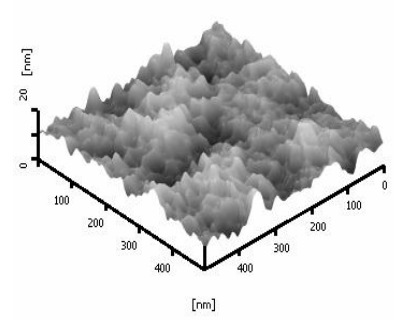

c. UF3 d. UF4

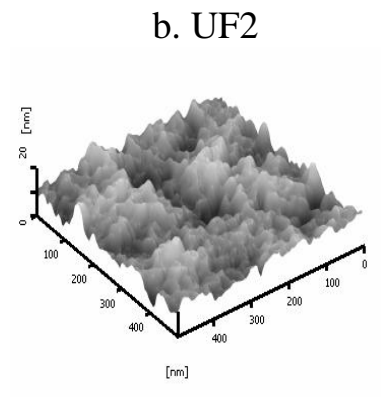

Gambar 4. Pandangan AFM tiga dimensi struktur morfologi membran hollow fiber bagian permukaan atas.

Hasil foto SEM terhadap semua jenis variasi komposisi membran pada penelitian ini diperlihatkan pada Gambar 3. Dapat dilihat bahwa perubahan komposisi larutan polimer berpengaruh terhadap struktur morfologi membran. Membran UF1 mempunyai ciri lapisan dense permukaan luar dan struktur sponge yang tebal, dan struktur macrovoid berbentuk oval. Lapisan dense yang tebal pada membran UF1 tidak terlihat lagi pada membran UF2.

Bentuk dan ukuran macrovoid membran UF2 berbeda dengan membran UF1, di mana bentuknya menjadi lonjong dan ukurannya lebih panjang. Struktur morfologi membran UF3 dan UF4 berbeda lagi dengan membran UF1 dan UF2, di mana bentuk dan ukuran struktur macrovoid berubah dan lebih panjang. Perubahan struktur pori membran ini berhubungan dengan proses induksi non-pelarut ke dalam polimer matrik, dan proses pelepasan pelarut dari polimer ke dalam larutan non-pelarut saat terjadi solidifikasi membran (Lalia dkk., 2013).

\section{Struktur Morfologi Permukaan Membran}

Struktur morfologi permukaan membran perlu dianalisis khususnya untuk mengetahui sifat kekasaran membran (membrane surface roughness). Struktur permukaan membran ini berhubungan erat dengan pembentukan fouling yang dapat menghambat proses filtrasi jika air banyak mengandung bahan organik alami (natural organic matter). Paramater yang diamati untuk mengetahui tingkat kekasaran membran adalah mean roughness (Ra). Ra merupakan nilai rata-rata selisih tinggi

antara puncak dan lembah struktur nodule (peak and valley). Stuktur nodule adalah bagian benbentuk bukit berwarna lebih putih pada permukaan membran. Bagian yang berwarna lebih gelap menunjukkan struktur pori (Gambar 4).

Berdasarkan hasil pengamatan didapatkan data Ra masing-masing untuk membran UF1, UF2, UF3, dan UF4 adalah 1,695; 2,92; 2,20; dan 2,41. Dapat diketahui bahwa parameter Ra membran modifikasi dengan MPC (UF2, UF3, dan UF4) lebih tinggi daripada membran tanpa modifikasi (UF1). Namun dari data yang diperoleh tidak bisa disimpulkan kecenderungan korelasi antara konsentrasi MPC dengan parameter Ra.

\section{Permeabilitas Air dan Kemampuan Rejeksi Partikel}

Parameter kinerja membran yang juga penting adalah permeabilitas air atau fluks dan rejeksi solut atau kemampuan menolak partikel dalam larutan tertentu. Permeabilitas air merupakan jumlah volume air yang tersaring melewati lapisan membran persatuan luas permukaan membran, waktu penyaringan, dan tekanan operasi. Rejeksi solut adalah jumlah partikel dalam larutan tertentu dan dengan konsentrasi tertentu yang tertahan oleh lapisan membran dan terbawa bersama larutan retentat dalam satuan persen. Membran dengan kinerja filtrasi yang baik adalah membran yang mempunyai permeabilitas air tinggi dan juga rejeksi solut tinggi.

Membran UF2 adalah hasil modifikasi larutan dope dengan penambahan 0,5\% MPC. Kehadiran MPC dalam matrik polimer menghasilkan membran dengan struktur pori yang lebih banyak dan dengan ukuran pori yang lebih panjang sebagaimana telah dijelaskan pada bagian 3.1. Penambahan MPC lebih tinggi dari $0,5 \%$ menghasilkan membran dengan struktur pori yang lebih panjang juga, namun memberi efek terhadap peningkatan lapisan dense dekat permukaan luar dan dan permukaan dalam membran, serta penyempitan pori pada struktur sponge. Gambar 5 memperlihatkan profil permeabilitas air semua membran dengan berbagai komposisi membrane modifying agent. Dapat dipahami bahwa membran UF2 memiliki nilai permeabilitas air paling tinggi yaitu mencapai 146 $\mathrm{L} / \mathrm{m}^{2}$.jam.atm. Akibatnya, proses filtrasi menjadi terhambat, sehingga terjadi penurunan jumlah permeabilitas air sebagaimana terlihat pada Gambar 5. Fenomena peningkatan lapisan dense dan penyempitan pori pada struktur sponge ini berhubungan dengan pengingkatan viskositas larutan polimer (larutan dope). Pada konsentrasi yang lebih tinggi, aditif MPC ini dapat berperan sebagai polimer, sehingga konsentrasi total larutan 


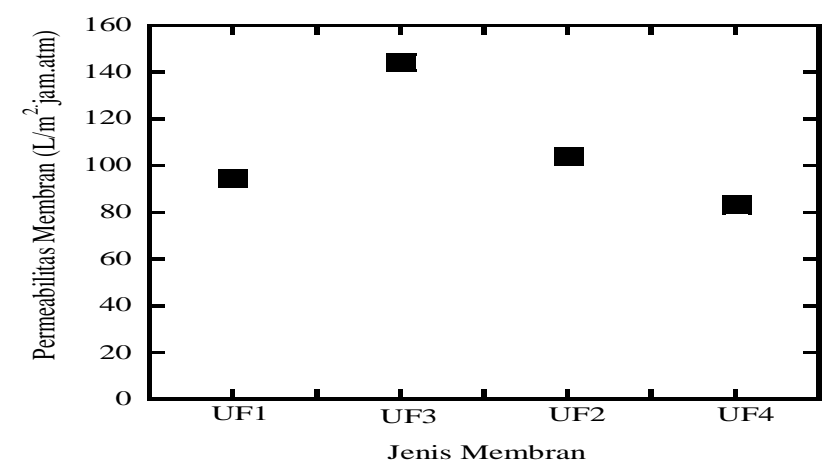

Gambar 5. Permeabilitas deionized water pada berbagai jenis membran.

polimer jadi meningkat. Peningkatan konsentrasi larutan polimer berakibat pada penundaan proses pemisahan fasa larutan polimer di dalam bak koagulasi sebagai solidifikasi membran.

Kemampuan rejeksi terhadap larutan asam humat pada semua jenis membran diperlihatkan pada Gambar 6. Nilai rejeksi membran UF1 dan UF4 mendekati $100 \%$. Sementara membran UF2 dan UF3 sedikit lebih rendah, namun semua membran masih berada di atas 90\%. Dalam aplikasinya, target rejeksi partikel oleh membran sangat tergantung kepada ukuran diameter partikel bahan yang akan dipisahkan. Target rejeksi ini bisa dikontrol pada saat proses pembuatan larutan polimer.

\section{Kinerja Membran untuk Pengolahan Air Sumur Tercemar Limbah Tsunami}

Untuk mengetahui kinerja filtrasi membran yang telah dibuat dalam aplikasinya untuk pengolahan air bersih, maka digunakan sampel air sumur masyarakat Desa Jelingke, Kota Banda Aceh sebagai larutan umpan. Sampel air sumur terlebih dahulu dilakukan pre-screening dengan membrane syringe filter $0,45 \mu \mathrm{m}$. Proses filtrasi dilakukan dengan tekanan modul yang sama untuk semua jenis membran yaitu 0,5 atm. Hasil analisis air sumur sebelum dan setelah perlakuan dengan membran (permeat) terhadap beberapa paremeter kualitas air dipaparkan pada Tabel 1.

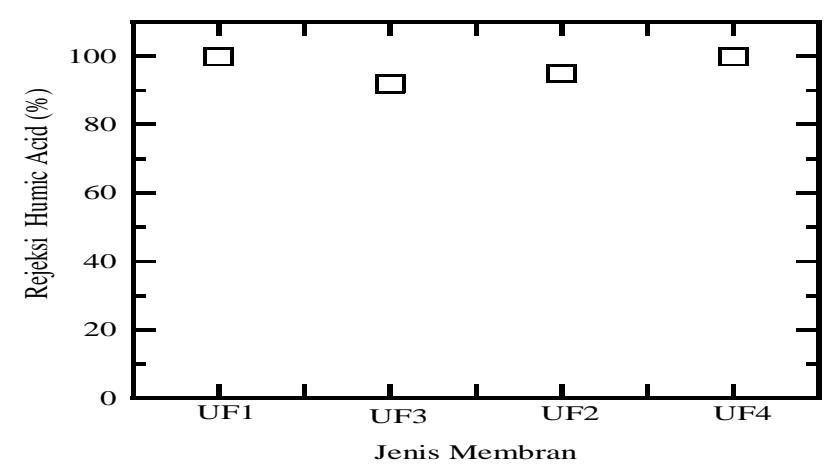

Gambar 6. Rejeksi partikel asam humat oleh berbagai jenis membran

Dari Tabel 1 dapat dilihat bahwa sampel air sumur memiliki total zat padat terlarut yang melampaui nilai baku mutu. Demikian juga dengan kandungan klorida nilainya hampir 5 kali lebih besar dari standar baku mutu. Dapat dipahami bahwa air sumur yang menjadi sampel pada penelitian ini mengandung garam yang cukup tinggi. Setelah dilakukan proses filtrasi dengan kondisi operasi seperti yang telah dijelaskan sebelumnya pada artikel ini, didapatkan bahwa semua parameter kualitas air dapat diturunkan sampai dibawah standar baku mutu sesuai permenkes nomor 907/MENKES/SK/VII/2002. Ke-empat membran mampu menyisihkan parameter biologi total coliform dan E. Coli sebesar $100 \%$. Untuk TDS, keempat membran hanya mampu disisihkan di atas $80 \%$. Walaupun parameter klorida sedikit di atas baku mutu namun mampu disisihkan lebih dari 3.

\section{KESIMPULAN}

Empat jenis membran hollow fiber telah dibuat dengan memodifikasikan komposisi polimer polyethersulfone dan aditif 2-(metakriloilosi)etil posporil klorin, serta polivinil pirolidonpirrolidone. Diperoleh membran dengan perubahan struktur morfologi yang mengikuti tendensi pembesaran ukuran struktur macrovoid pada komposisi MPC 0,5\%. Penambahan MPC lebih besar dari 0,5\% menghasilkan membran dengan sruktur dense yang

Tabel 1. Kualitas air sumur sebelum dan sesudah filtrasi dengan membran

\begin{tabular}{lrrrrrr}
\hline \multirow{2}{*}{ Parameter kualitas air } & \multirow{2}{*}{ Standar* } & \multirow{2}{*}{ Sampel air sumur } & \multicolumn{4}{c}{ Hasil penyaringan dengan membran } \\
\cline { 4 - 7 } & & & UF1 & UF2 & UF3 & UF4 \\
\hline Kekeruhan $(\mathrm{mg} / \mathrm{L})$ & 25 & 11,8 & 2,25 & 1,95 & 5,12 & 2,6 \\
$\mathrm{TDS}(\mathrm{mg} / \mathrm{L})$ & 1500 & 5965 & 1090 & 1080 & 1175 & 1040 \\
$\mathrm{pH}$ & $6,5-8,5$ & 7,0 & 7,55 & 7,40 & 7,26 & 7,49 \\
$\mathrm{CaCO}$ & 500 & 420 & 96,0 & 84,0 & 60 & 72,0 \\
$\mathrm{Klorida}_{3}(\mathrm{mg} / \mathrm{L} / \mathrm{L})$ & 250 & 1180 & 334 & 351,45 & 376,3 & 358,55 \\
$\mathrm{NO}_{3}(\mathrm{mg} / \mathrm{L})$ & 10 & 4,9 & 0,32 & 0,61 & 0 & 0,83 \\
$\mathrm{NO}_{2}(\mathrm{mg} / \mathrm{L})$ & 1 & 0,32 & 0,05 & 0,045 & 0,03 & 0,075 \\
Total Coliform & 0 & 2970 & 0 & 0 & 0 & 0 \\
E. coli & 0 & 735 & 0 & 0 & 0 & 0 \\
\hline *Standar baku mutu kularyyyyyy
\end{tabular}

*Standar baku mutu kualitas air, Peraturan Kementerian Kesehatan : 907/MENKES/SK/VII/2002 
lebih tebal serta struktur sponge lebih panjang. Kinerja filtrasi menggunakan air deionisasi menghasilkan permeabilitas air maksimal pada system PES 20\%/MPC 0,5\%. Uji filtrasi terhadap air sumur masyarakat di area terimbas tsunami memberikan hasil bahwa semua parameter uji kualitas air dapat diturunkan hingga dibawah batas standar baku mutu kualitas air sesuai Surat Keputusan Menteri Kesehatan.

\section{UCAPAN TERIMAKASIH}

Penulis mengucapkan terima kasih kepada Direktorat Penelitian Pengabdian kepada Masyarakat, Direktorat Jenderal Pendidikan Tinggi, Kementerian Pendidikan dan Kebudayaan atas biaya Hibah Penelitian Bagi Dosen Perguruan Tinggi yaitu Penelitian Fundamental Tahun Anggaran 2015 dengan SK Nomor : 059/UN11.2/LT/SP3/2015.

\section{DAFTAR PUSTAKA}

Arahman, N., Arifin, B., Mulyati, S., Ohmukai, Y., dan Matsuyama, H., 2011. Improved Fouling Reduction of PES Hollow Fiber Membranes by Incorporation with Non-ionic Surfactant. Research Journal of Chemistry and Environment, 15:212-216,

Baker, R.W. 2004. Membrane Technology and Applications. John Wiley \& Sons, Hoboken.

Chowdhury, S., Champagne, P. dan McLellan, J., 2010. Investigating Effects of Bromide Ions on Trihalomethanes and Developing Model for Predicting Bromodichloromethane in Drinking Water. Water Research, 44(7):2349-2359.

Chu, W., Gao, N., Yin, D., dan Krasner, A.W., 2013. Formation and Speciation of Nine Haloacetamides, an Emerging Class of Nitrogenous DBPs, During Chlorination or Chloramination. Journal of Hazardous Material, 260:806-812.

Culin, J., dan Mustac, B., 2015. Environmental Risks Associated with Ballast Water Management Systems that Create Disinfection By-Products (DBPs). Ocean \& Coastal Management, 105:100-105.

Ilyas, M, Arahman, N, dan Tarmizi, S.A., 2006. Kualitas Air Sumur Perumahan Masyarakat Kota Banda Aceh Pasca Bencana Alam Gempa Bumi dan Tsunami 26 Desember 2004. Laporan hasil penelitian. Kerja sama dengan Japan NGO Network on Indonesia (JANNI).

Kumari, M., Gupta, S.K., dan Mishra, B.K., 2015. Multi-exposure Cancer and Non-cancer Risk Assessment of Trihalomethanes in Drinking Water Supplies - A Case Study of Eastern region of India. Ecotoxicology and Environmetal Safety, 113:433-438.

Kumar, R., Isloor, A.M., Ismail, A.F., dan Matsura, $\mathrm{T}$, 2013. Performance Improvement of Polysulfone Ultrafiltration Membrane Using Nsuccinyl Chitosan as Additive. Desalination, 318:1-8

Lalia, B.S., Kochkodan, V., Hashaikeh, R., dan Hilal, N., 2013. A Review on Membrane Fabrication: Structure, Properties and Performance Relationship, Desalination, 326:77-95.

Martín, A., Arsuaga, J.M., Roldán, N., Abajo, J., Martínez, A., dan Sotto, A., 2015. Enhanced Ultrafiltration PES Membranes Doped with Mesostructured Functionalized Silica Particles. Desalination, 357:16-25.

Matsumaru, R., Nagami, K., dan Takeya, K., 2012. Reconstruction of the Aceh Region Following the 2004 Indian Ocean Tsunami Disaster: A Transportation Perspective. IATSS Research, 36:11-19.

Miswadi, S.S., 2009. Kajian Spasial Kualitas Air Tanah Bebas Berdasarkan Kedalaman Muka Air Tanah: Studi Kasus di Daratan Aluvial Das Pemali Kabupaten Brebes. Jurnal Manusia dan Lingkungan, 16(2):103-114.

Mohammad, A.W., Teow, Y.H., Ang, W.L., Chung, Y.T., Oatley-Radcliffe, D.L., dan Hilal, N., 2015. Nanofiltration Membranes Review: Recent Advances and Future Prospects. Desalination, 356:226-254.

Pearce, G, 2007. Introduction to Membranes: Filtration for Water and Wastewater Treatment. Filtration+Separation, 44:24-27.

Su, Y-N., Lin, W-S., Hou, C-H, dan Den, W., 2015. Performance of Integrated Membrane Fltration and Electrodialysis Processes for Copper Recovery from Water Polishing Wastewater. Journal of Water Process Engineering, 4:149158.

Sun, Y-X., Wu, Q-Y., Hu, H-Y., dan Tian, J., 2009. Effect of Ammonia on the Formation of THMs and HAAs in Secondary Effluent Chlorination. Chemosphere 76:631-637.

Tokmak, B., Capar, G., Filiz B. Dilek, dan Ulku Yetis, 2004. Trihalomethanes and Associated Potential Cancer Risks in the Water Supply in Ankara, Turkey. Environmental Research 96:345-352.

Widyastuti, M., Sudarmadji, Sutikno, dan Hendrayana, H., 2012. Kerentanan Ait Tanah terhadap Pencemaran Daerah Imbuhan Ponor di Karst Gunung Sewu (Studi di Daerah Aliran Bawah Tanah Bribin). Jurnal Manusia dan Lingkungan, 19(2):128-142 